\title{
Effects of iron-ore mining and processing on metal bioavailability in a tropical coastal lagoon
}

\author{
Adriana Alves Pereira • Bert van Hattum • \\ Abraham Brouwer • Peter Michiel van Bodegom • \\ Carlos Eduardo Rezende • Wim Salomons
}

Received: 3 March 2008 / Accepted: 14 July 2008 / Published online: 15 August 2008

(C) The Author(s) 2008. This article is published with open access at Springerlink.com

\begin{abstract}
Background, aim, and scope In water systems, water quality and geochemical properties of sediments determine the speciation of trace metals, metal transport, and sediment-water exchange, influencing metal availability and its potential effects on biota. Studies from temperate climates have shown that iron-ore mining and tailing wastewaters, besides being a source of trace metals, usually show high levels of dissolved ions and particulate suspended matter, thus having the potential of indirectly changing metal bioavailability. For the first time in the tropics, we identified the effects of iron-ore mining and processing on metal bioavailability in a coastal lagoon. With an extensive sampling scheme, we investigated the potential sources of metals; the links among metal levels in water, sediments, and invertebrates; and the contrasting effects on metal speciation and bioavailability.

Methodology The metals $\mathrm{Fe}, \mathrm{Mn}, \mathrm{Al}, \mathrm{Cr}, \mathrm{Zn}, \mathrm{Cu}, \mathrm{Ni}, \mathrm{Pb}$, $\mathrm{Cd}, \mathrm{Hg}$, and As were measured in water, sediments (surface
\end{abstract}

Responsible editor: Henner Hollert

A. A. Pereira $(\bowtie) \cdot$ B. van Hattum $\cdot$ A. Brouwer $\cdot$ W. Salomons Institute for Environmental Studies, Vrije Universiteit,

De Boelelaan 1087,

1081HV Amsterdam, The Netherlands

email: adriana.pereira@ivm.falw.vu.nl

P. M. van Bodegom

Department of Systems Ecology, Vrije Universiteit,

De Boelelaan 1085,

1081 HV Amsterdam, The Netherlands

C. E. Rezende

Centro de Biociências e Biotecnologia, Laboratório de Ciências

Ambientais, Universidade Estadual do Norte Fluminense,

Alberto Lamego 2000,

CEP 28013-600 Campos dos Goytacazes, Rio de Janeiro, Brazil and profiles), and invertebrates from Mãe-Bá Lagoon and in the sites directly influenced by the mining operations (tailing dams and nearby rivers). In addition, samples from two other lagoons, considered pristine, were analyzed. The study area is located in the southeast of Brazil (Iron Quadrangle Region and a coastal area of Espírito Santo State). General water characteristics included $\mathrm{pH}$, dissolved organic carbon, alkalinity, and anion composition. Water metal speciation was assessed by a speciation model (Chemical Equilibria in Aquatic Systems). Grain-size distribution, organic carbon, carbonate, and acid volatile sulfide (AVS) were determined in sediments. Statistical methods included comparison of means by Mann-Whitney test, ordination and correlation analyses, and analysis of regression for geochemical normalization of metals with grain size.

Results and discussion The dissolved metal concentrations, the total metal levels in sediments, and the normalization based on the fine sediment fraction showed that the mining operations constitute potential sources of $\mathrm{Fe}, \mathrm{Mn}, \mathrm{Cr}, \mathrm{Cu}$, $\mathrm{Ni}, \mathrm{Pb}, \mathrm{As}$, and $\mathrm{Hg}$ to Mãe-Bá Lagoon. However, trace metal availability was reduced because of increased $\mathrm{pH}$, hardness, and sulfide content $(356 \mu \mathrm{mol} / \mathrm{g})$ in the sites influenced by the mining. The lagoon showed similar water chemistry as in the mining sites, with metal bioavailability further decreased by the presence of dissolved organic carbon and chloride. Although AVS levels in the lagoon were low $(0.48-56 \mu \mathrm{mol} / \mathrm{g})$, metal bioavailability was reduced because of the presence of organic matter. Metal levels in invertebrates confirmed the predicted low metal bioavailability in Mãe-Bá Lagoon. The lagoon was considered moderately contaminated only by $\mathrm{Hg}$ and As.

Conclusions The iron-ore mining and processing studied here constitute potential sources of metal pollution into the tropical lagoon. Contrary to expectations, however, it also 
contributes to reducing the overall metal bioavailability in the lagoon.

Recommendations and perspectives These findings are believed to be useful for evaluating metal exposure in a more integrated way, identifying not only the sources of pollution but also how they can affect the components involved in metal speciation and bioavailability in water systems, leading to new insights.

Keywords Bioavailability · Iron-ore mining · Speciation . Trace metals $\cdot$ Tropical lagoon

\section{Background, aim, and scope}

Mining and associated smelting and metal processing activities have led to perturbations in the cycling of metals in the surface environment. In this context, iron-ore mines act as important sources of major metals, mainly $\mathrm{Fe}$ and $\mathrm{Mn}$, but also associated trace metals into the environment (Ratha and Venkataraman 1995; Wong 1981; Zabowski et al. 2001). Studies from temperate climates have shown that iron-ore mining and its tailing wastewaters usually show high levels of dissolved ions and particulate suspended matter, thus changing the water chemistry (Holopainen et al. 2003) and the bioavailability of metals.

This study aimed to identify the effects of iron-ore mining and processing on metal bioavailability in tropical coastal lagoons, which hitherto remained unstudied. Through an integrated characterization of general water chemistry, geochemical composition of the sediments, acid volatile sulfide (AVS), and metal concentrations in sediments, water, and invertebrates, we investigated the potential sources of metals, the links among metal levels in different compartments, and the contrasting effects on metal speciation and bioavailability.

The study area is located in Minas Gerais State (Iron Quadrangle Region) and in Espírito Santo State, Brazil (Fig. 1), which has an extensive iron-ore mining and processing plant. Various studies have confirmed the environmental contamination by trace metals in the Iron Quadrangle (de Mello et al. 2006; Matschullat et al. 2000; Pimentel et al. 2003). However, most of these studies were concentrated in gold mining areas, focused on arsenic and mercury contamination, and did not include information about metal bioavailability.

\section{Materials and methods}

\subsection{Study area}

The study area includes the water resources influenced by the activities of the iron-ore mining and the pelletizing plant located in the southeast of Brazil, named Samarco Mineração S/A. In 2007, Samarco produced 14 million tons of iron pellets that contained around $67 \%$ iron. Samarco has two industrial sites (see Fig. 1): a mining complex with a concentration plant, located in the city of Mariana, Minas Gerais State (Germano Site), and a pelletizing plant with port facilities, located in the city of Anchieta, Espírito Santo State (Ponta Ubu Site). At the mining complex, effluents with high content of solids are produced and treated in two settling dams, named Germano and Santarém. The treated effluents flow to Santarém Creek and reach the Gualaxo do Norte River, which is part of the Doce River hydrographic basin. A pipeline (396 km long) transports the ore mixed with water

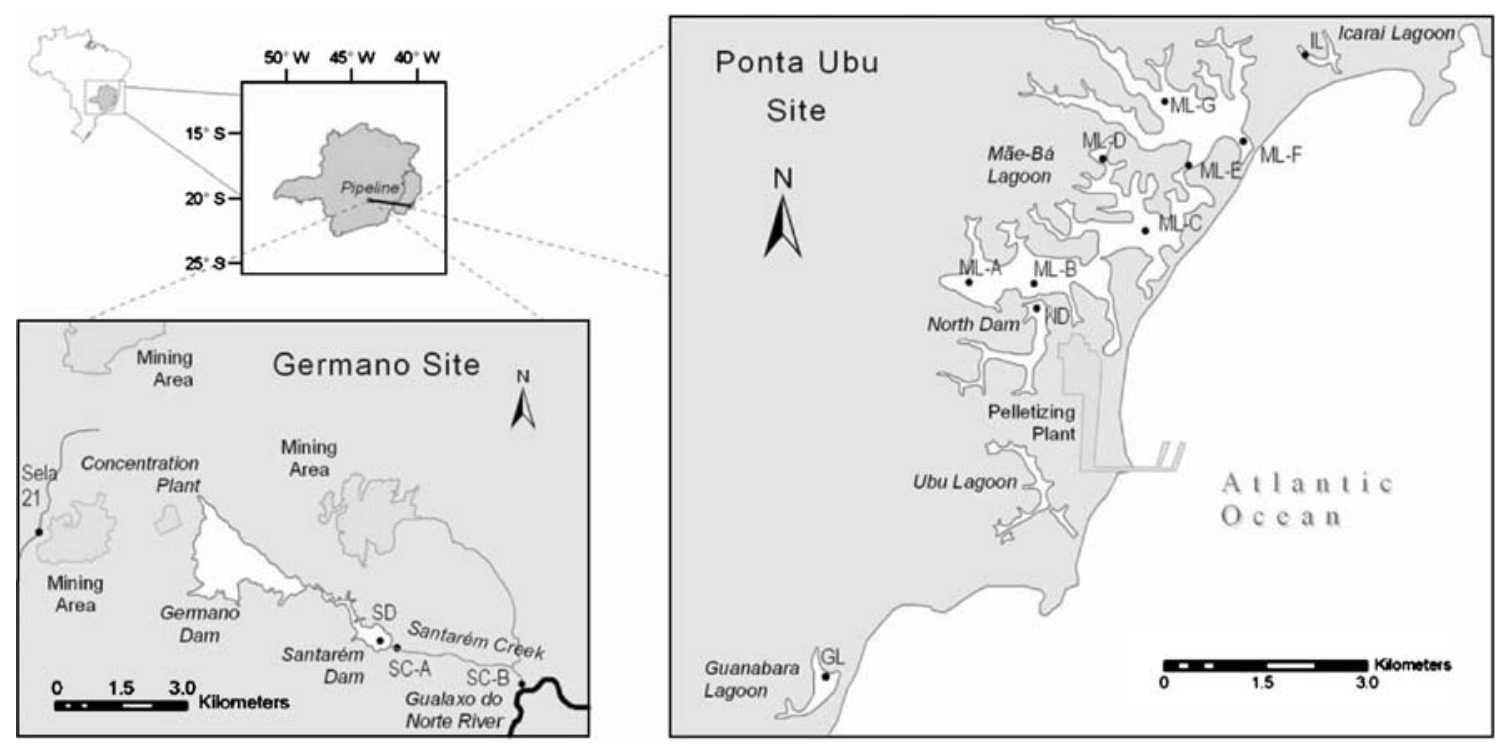

Fig. 1 Location map of the studied area with the position of the sites 
(slurry) to the pelletizing plant. In this plant, the ore is separated from the water and the effluent goes to an artificial lake (North Dam). Periodically, this artificial lake overflows into Mãe-Bá Lagoon. Mãe-Bá Lagoon is a coastal lagoon with no superficial connection to the sea. It has an area of $5.0 \mathrm{~km}^{2}$ and an average depth of $1.9 \mathrm{~m}$. The lagoon also receives untreated sewage from around 3,500 people. There has been an increase in the eutrophication process in the lagoon during the last decade (Pereira et al. 2006).

\subsection{Sampling and analysis}

The 14 selected sampling sites are shown in Fig. 1. Sela21 was selected as a reference site for the mining area because it is not influenced by the industrial processes and reflects the natural mineralization in the area. Site SD was located in the tailing dam (Santarém Dam). The sites located at Santarém Creek represented the direct influence of the mining operations in the Gualaxo do Norte River (site SCA) and the additional influence of other iron mining sites located in the area (site SC-B). In the coastal area, one site was sampled at North Dam (site ND) and seven sites at Mãe-Bá Lagoon (sites ML-A to ML-G). Additionally, two nearby coastal lagoons (Icaraí and Guanabara Lagoons), which have similar water characteristics to Mãe-Bá Lagoon but do not receive effluents from any industrial processes, were selected as Reference Lagoons (sites IL and GL). Outfield trips took place in January and July 2006.

\subsection{Surface water}

Sampling flasks were acid-soaked and washed with distilled deionized water before use. Samples were kept on ice in the field and filtered within $3 \mathrm{~h}$ in the laboratory through a $0.45-\mu \mathrm{m}$ cellulose acetate membrane filter. Blanc samples were provided in the field using distilled deionized water and were treated in the same way as the samples.

Analyses of $\mathrm{Ca}, \mathrm{K}, \mathrm{Mg}, \mathrm{Na}, \mathrm{Al}$, and $\mathrm{Fe}$ were performed with inductively coupled plasma-atomic emission spectrometry (ICP-AES); $\mathrm{Mn}, \mathrm{Zn}, \mathrm{Cd}, \mathrm{Pb}, \mathrm{Cu}, \mathrm{Ni}, \mathrm{Cr}$, and $\mathrm{As}$ with ICP mass spectrometry (ICP-MS); and Hg with cold vapour atomic fluorescence spectrometry (CV-AFS), according to standard methods (APHA 1998). Water samples for alkalinity and anion composition were collected in 1-L polyethylene bottles and analyzed within $24 \mathrm{~h}$. Main water characteristics (alkalinity, $\mathrm{Cl}^{-}, \mathrm{NO}_{3}^{-}, \mathrm{NO}_{2}^{-}, \mathrm{SO}_{4}^{2-}$, and $\mathrm{PO}_{4}^{3-}$ ) were determined using standard procedures (APHA 1998). Water temperature, dissolved oxygen, salinity, $\mathrm{pH}$, and conductivity were measured in situ using a calibrated multiprobe water quality meter.

For the analyses of suspended particulate matter (SPM), particulate organic carbon (POC), total particulate nitrogen (TPN), and dissolved organic carbon (DOC), samples were filtered over preweighted, $25-\mathrm{mm}$ glass-microfiber filters. The filters were oven-dried and weighted for determination of SPM. Determination of POC and TPN was performed with a CHN/S analyzer. DOC was analyzed in the filtrates with a total organic carbon (TOC) analyzer.

The speciation model Chemical Equilibria in Aquatic Systems (CHEAQS) (Verweij 2005) was used to predict the relative distribution of dissolved metal species and the competing elements as a function of the constituents in water. The concentrations of inorganic components considered to affect metal species distribution ( $\mathrm{pH}$, [bi]carbonate, $\mathrm{Ca}, \mathrm{Mg}$, dissolved metals, etc.) were taken from sample measurements.

\subsection{Sediment}

Sediment cores were sampled at sites ND, ML-B, ML-C, MLG, and GL and surface sediments at the other locations (see Fig. 1). All samples were sieved in a 2-mm stainless steel sieve to remove gravel particles and large detritus. Samples were oven-dried at $50^{\circ} \mathrm{C}$ to constant weight. They were digested with aqua regia and metal analyses were performed according to Standard Methods (APHA 1998). Analyses of $\mathrm{Fe}, \mathrm{Mn}$, and $\mathrm{Zn}$ were performed with atomic absorption spectrophotometry (AAS) and $\mathrm{Al}, \mathrm{Cu}, \mathrm{Cd}, \mathrm{Ni}, \mathrm{Pb}$ and $\mathrm{Cr}$ were measured with graphite furnace atomization (GFA)AAS. Mercury was measured with CV-AFS and As was measured with ICP-AES with hydride generation system.

AVS, defined as the amount of sulfide that can be volatilized during a cold acid extraction, and the AVSbound metals, extracted at the same time and called simultaneously extracted metals (SEM), were analyzed on surface sediments according to Van Griethuysen et al. (2002). Metal bioavailability and potential toxicity were assessed by the difference between SEM and AVS using the methods described in Di Toro et al. $(1992,2002)$.

The sediment grain size distribution was analyzed with laser diffraction in a Laser Particle Sizer. Total carbon and total nitrogen $(\mathrm{TN})$ were analyzed using a $\mathrm{CHN} / \mathrm{S}$ elemental analyzer. TOC was calculated from total carbon after $\mathrm{CaCO}_{3}$ correction.

\subsection{Invertebrate}

Invertebrates were collected in the littoral substrates (macrophytes, benthic filamentous algae, and litter). Animals were sorted, washed with local water, and transported in polyethylene flasks to the laboratory, where they were counted and identified live with available keys. The collected species included freshwater snails Pomacea haustrum and Melanoides tuberculata (gastropods), Macrobrachium sp. and Ucides sp. (crustaceans), and water bugs belonging to the order Hemiptera. Invertebrates were held in distilled deionized water for gut clearance during $16 \mathrm{~h}$. 
Although mortality of some individuals occurred, partial gut clearance was observed by the presence of fecal pellets in the water. We assumed that this would not affect the tissues residues of the invertebrates. For the gastropods, the soft tissues were dissected for analysis, while for the other species, the whole organisms were taken. Organisms were stored frozen and freeze-dried. Samples were digested with $\mathrm{HNO}_{3} 70.5 \%$ and metal analyses were performed according to standard methods (APHA 1998). Metals were measured with ICP-MS, while Hg was measured with CV-AFS.

\subsection{Quality control}

The analytical quality of the metal determinations was monitored by comparison with the internal reference material IRM-488 for sediments and with DOLT-2 (dogfish liver homogenate from the National Research Council of Canada, Ottawa) for the organisms. Comparison of measured metal concentrations in the reference materials with the certified values $(n=12)$ showed that recovery of the metals was within $\pm 10 \%$. The only exception was $\mathrm{Cr}$ measured in invertebrate samples. Therefore, $\mathrm{Cr}$ concentrations in biota were used only for relative comparisons. The repeatability was monitored by duplicate analysis.

\subsection{Statistical analyses}

The effect of groups of sampling locations on metals in water, surface sediments, and invertebrates was tested. Three groups were selected: sites influenced by the mining (sites SD, SC-A and ND), Mãe-Bá Lagoon (sites ML-A to ML-G), and Reference Lagoons (sites GL and IL). Before statistical analysis, data were tested for normality using KolmogorovSmirnov test and for homogeneity of variance using Levene's test. As homogeneity of variance between groups could not be attained, the effect of location was tested using the Mann-Whitney test. In sediment profiles, metal enrichment was tested by comparing mean values in upper layers $(5-20 \mathrm{~cm})$ with deeper layers $(25-50 \mathrm{~cm})$ using MannWhitney test. Differences were considered significant if $P<$ 0.05 . One-sample $t$ tests were applied to compare mean values from an individual site with values from a group of locations (e.g., water characteristics at North Dam compared with mean values at Mãe-Bá Lagoon).

To identify patterns in the variability of metals across the various locations, ordination analyses were performed using Canoco 4.5 (Ter Braak and Smilauer 2002). First, we applied unconstrained ordination through a principal component analysis (PCA) to explain theoretical variations in the metal concentrations data. Secondly, a constrained ordination by a redundancy analysis (RDA) using Clay + Silt $(<63 \mu \mathrm{m})$ content, TOC content, sampling locations, and depths as environmental factors was used to describe variations in the metal concentrations as explained by these environmental conditions. The significance level used was 0.01. Correlations between environmental variables and the main axes of the ordination analyses were obtained using a Pearson's correlation.

In order to test relationships among the metals, correlation analyses were performed with all sedimentological and chemical data from Mãe-Bá Lagoon. A scatter plot matrix indicated a linear relationship between most of the variables [some of them needed log transformation, such as $\mathrm{Fe}, \mathrm{Mn}$, and Clay+Silt $(<63 \mu \mathrm{m})]$. Pearson's correlation coefficients (at 0.05 significance level) were calculated for all variables, except for $\mathrm{As}$ and $\mathrm{Cd}$, for which the data did not show a normal distribution, not even after transformation. The relationships between these metals and the other variables were therefore assessed by Spearman correlation.

A geochemical normalization of metals in sediments was applied for Mãe-Bá Lagoon as described in Loring and Rantala (1992). Because the mining effluent could be a source of metals such as $\mathrm{Fe}$ and $\mathrm{Al}$ to the lagoon, the application of a chemical normalization with a conservative element was impracticable. The decision for the best normalization approach was made after examination of the correlation matrix and an analysis of the possible anthropogenic inputs of contaminants. Statistical analysis showed a linear relationship between all metal concentrations, except $\mathrm{As}$ and $\mathrm{Cd}$, and Clay+Silt $(<63 \mathrm{~mm})$ content. Regression analysis was then used to determine the "natural" or "background" relationships between Clay+Silt $(<63 \mu \mathrm{m})$ content and the metals at MãeBá Lagoon and to identify the sites considered metalenriched. Logarithmic transformations to correct for nonconstant variance and nonnormality were applied for $\mathrm{Fe}, \mathrm{Mn}$, and Clay+Silt $(<63 \mu \mathrm{m})$, to ensure the assumptions used in linear regression models (Everitt and Dunn 2001). The data were examined for statistical outliers and influential cases using Cook's distance and residual plots. Outliers that fell above the potential regression line and represented possible enrichment were removed prior to fitting the final regression model. For each metal, the $95 \%$ confidence interval for "natural" concentrations was calculated for each sample by the regression equations. Points lying above the upper limit were considered potentially influenced by anthropogenic sources. Statistical data analysis was performed using the software package SPSS for windows (Statistical Package SPSS version 15.0, Chicago, IL, USA).

\section{Results and discussion}

\subsection{Dissolved trace metals and water quality}

The dissolved trace metals in the studied area were homogenously distributed and mostly below the maximum 
recommended standards of the Brazilian Federal Resolution Conama $357 / 05$ for the protection of aquatic life in freshwaters (Brasil 2005) (Table 1). Exceptions were Mn in Santarém Dam $(304 \mu \mathrm{g} / \mathrm{L})$ and in Santarém Creek (SCA, $237 \mu \mathrm{g} / \mathrm{L}$ ), Fe in Santarém Creek (SC-B, $0.50 \mathrm{mg} / \mathrm{L}$ ), in two locations at Mãe-Bá Lagoon (ML-A, $0.55 \mathrm{mg} / \mathrm{L}$; ML$\mathrm{G}, 0.34 \mathrm{mg} / \mathrm{L})$ and in Guanabara Lagoon $(0.52 \mathrm{mg} / \mathrm{L})$ and also $\mathrm{Al}$ in North Dam $(0.28 \mathrm{mg} / \mathrm{L})$, in all sites from Mãe-Bá Lagoon $(0.22,0.15,0.30,0.41,0.22,0.14$, and $0.14 \mathrm{mg} / \mathrm{L})$, and in Guanabara Lagoon $(0.19 \mathrm{mg} / \mathrm{L})$.

Water quality at the sites SD, SC-A, and ND reflected the mining activities and ore processing since some variables, such as alkalinity, sulfate, $\mathrm{pH}, \mathrm{Na}$, and $\mathrm{Hg}$, were higher in these sites compared to Sela21 (one sample $t$ test, $P<0.05$ ) (Table 2). Moreover, levels of alkalinity, Ni, Cd, and $\mathrm{Hg}$ were higher in these sites compared to Mãe-Bá Lagoon (Mann-Whitney test, $P<0.05$ ). Other parameters, such as sulfate, $\mathrm{Ca}, \mathrm{Na}$, and As, were higher only at North Dam compared to Mãe-Bá Lagoon (one sample $t$ test, $P<$ 0.001 ). These parameters, besides being influenced by ironore mining, were probably influenced by the chemicals added to control the concentration process and the $\mathrm{pH}$ of the slurry, like $\mathrm{NaOH}, \mathrm{CaO}$, and $\mathrm{CO}_{2}$ (Costa et al. 2003).

The $\mathrm{C} / \mathrm{N}$ atomic ratios $[(\mathrm{C} / \mathrm{N}) \mathrm{a}]$ in particulate matter at the Mãe-Bá Lagoon, ranging from 6.3 to 7.1 (see Table 2), indicated an origin from autochthonous production primarily derived from phytoplankton rather than from other aquatic plants and allochthonous sources. Levels of alkalinity, sulfate, $\mathrm{Cl}^{-}, \mathrm{Ca}, \mathrm{Na}, \mathrm{DOC}$, and $\mathrm{pH}$ were higher at Mãe-Bá Lagoon compared to the Reference Lagoons (Mann-Whitney test, $P<0.05$ ).

\subsection{Total trace metals in sediments and sediments characteristics}

Surface sediments (top $5 \mathrm{~cm}$ ) in the dams (SD and ND) were characterized as "clay to silt" (fraction $<63 \mu \mathrm{m}$ : $68 \%$ and $99 \%$, respectively) with low OC content $(<1.5 \%)$, while surface sediments at Mãe-Bá Lagoon were characterized as "silt to sand" (fraction $<63 \mu \mathrm{m}$ : 4.4 to $56 \%$ ), with higher organic carbon (2.0 to $18 \%$ ) content (Table 3). Carbonates were not found at the study area, except at ND (4.1\%).

Concentrations of metals at the mining area were mostly above the background values for Gualaxo do Norte River Basin (Costa et al. 2003). Levels of $\mathrm{Cr}, \mathrm{Hg}$, and As were generally higher than the quality criteria defined by Conama 344/04 (level 2, above which adverse biological effects are likely to occur) at the mining sites and ND (Brasil 2004) (see Table 3). A comparison with mean shale (MS) values (Salomons and Förstner 1984) shows higher levels of $\mathrm{Fe}, \mathrm{Mn}, \mathrm{Cr}, \mathrm{Hg}$, and $\mathrm{As}$ at the mining sites and $\mathrm{ND}$, and also higher levels of $\mathrm{Pb}$ and $\mathrm{Hg}$ at $\mathrm{ND}$, at some locations at Mãe-Bá Lagoon and at Guanabara Lagoon. Concentrations of $\mathrm{Al}, \mathrm{Cu}, \mathrm{Cd}, \mathrm{Zn}$, and $\mathrm{Ni}$ were lower than MS at all sampling sites.

Concentrations of $\mathrm{Fe}, \mathrm{Mn}, \mathrm{Cr}, \mathrm{Cu}, \mathrm{Hg}$, and As showed a decreasing gradient from sites located in the mining area to the sites located at the coastal area (Mann-Whitney Test, $P<0.05)$. This pattern was also apparent in all sediment results of the ordination analysis.

Mercury concentrations in sediments from Mãe-Bá Lagoon were much higher than reported sediment background concentrations for Brazilian lakes $(0.03 \mathrm{mg} / \mathrm{kg})$ (Lacerda and Salomons 1997), and also higher than the background level suggested for tropical areas $(0.05 \mathrm{mg} / \mathrm{kg})$ (Lacerda et al. 1993). Generally, $\mathrm{Hg}$ and As levels in surface sediments from Mãe-Bá Lagoon (0.07-0.37 and $1.7-8.8 \mathrm{mg} / \mathrm{kg}$, respectively) were in the same range as in other Brazilian coastal lagoons considered moderately contaminated by these metals (Lacerda and Goncalves 2001; Marins et al. 1998; Mirlean et al. 2003; Sousa et al. 2004). On the other hand, concentrations of $\mathrm{Zn}, \mathrm{Cu}, \mathrm{Ni}, \mathrm{Cr}$, $\mathrm{Cd}$, and $\mathrm{Mn}$ in the sediments from Mãe-Bá Lagoon were in the same range as those described for other Brazilian coastal lagoons considered noncontaminated by these metals (Knoppers et al. 1990; Silva and Rezende 2002).

PCA with all sediment data described $83.5 \%$ of the total variance in metal data. The PCA axes were significantly correlated to various metal variables. RDA indicated that the majority of the variance $(56 \%)$ potentially explained by unconstrained ordination was indeed related to the specified environmental conditions (i.e., sampling locations and sediment characteristics). From the total explained variance in metal data, the two first RDA axes explained $46 \%$ of the total variance (Fig. 2). The first axis accounted for $37 \%$ of the variation and was significantly correlated to the trace elements $\mathrm{Cu}, \mathrm{Ni}, \mathrm{Cr}$, and $\mathrm{Hg}$. The second axis explained 9\% of the variation and was significantly correlated to $\mathrm{Al}, \mathrm{Zn}$, $\mathrm{Fe}$, and $\mathrm{Pb}$. The location "Mine Area" was the most important environmental condition explaining the differences in metal concentrations in the study area in both axes. This means that sites located in the mining area deviated from the other sites with respect to both major and trace elements. The same applied to the surface layer of North Dam, which was located close to the mining sites (see Fig. 2). The differences in total variance in metal concentrations from the other sites (North Dam, excluding surface layer, Reference Lagoons and Mãe-Bá Lagoon) were mainly determined by Clay+Silt $(<63 \mathrm{~mm}), \mathrm{TN}$, and TOC contents.

Trace metals and sediment characteristics were also analyzed at various depths at five locations (Fig. 3). In general, differences in metal concentrations reflected the physical characteristics of the sediments at different depths. Higher metal levels were observed in layers of finer 


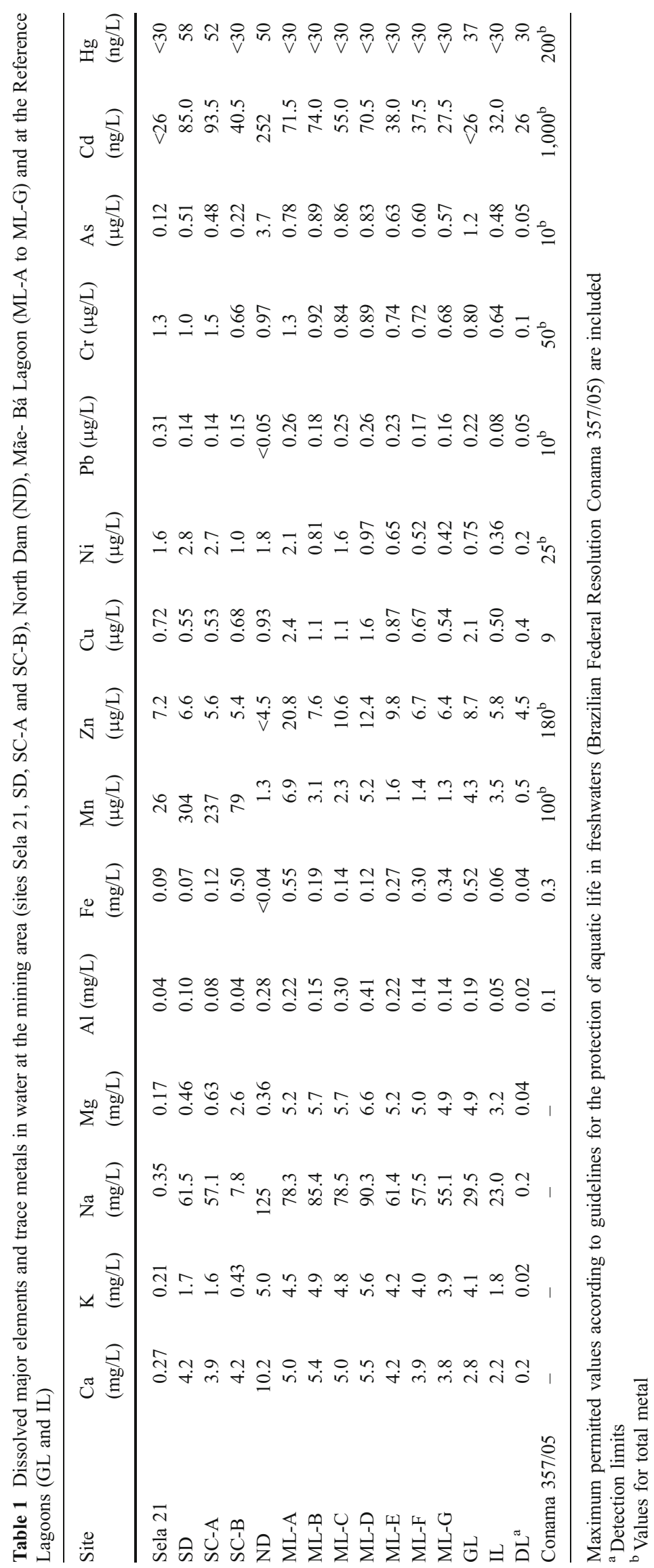




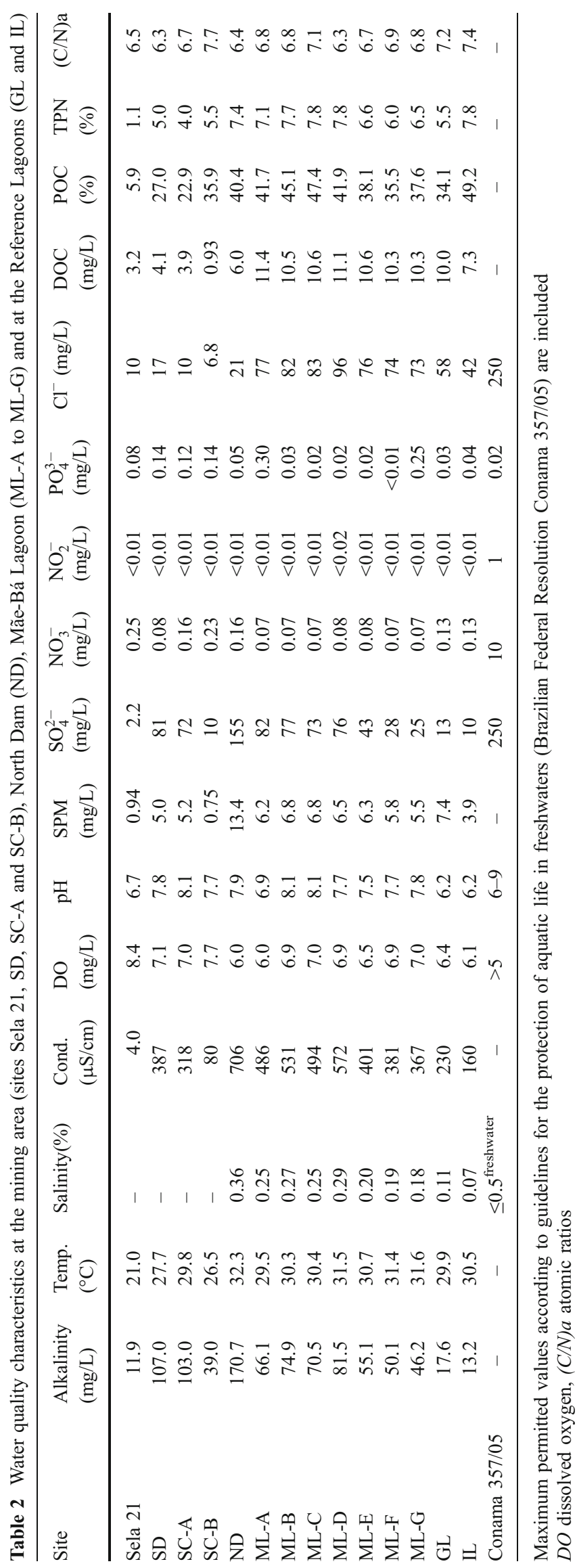




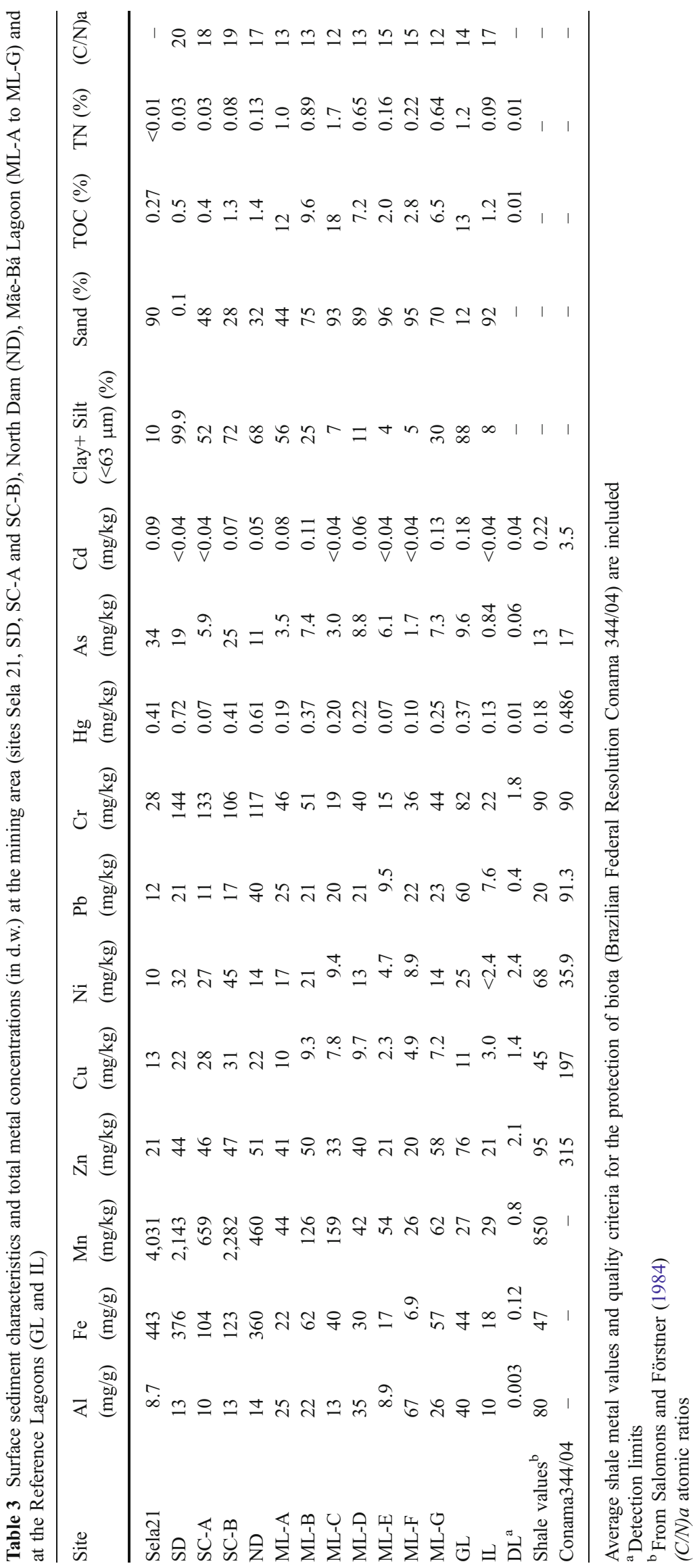




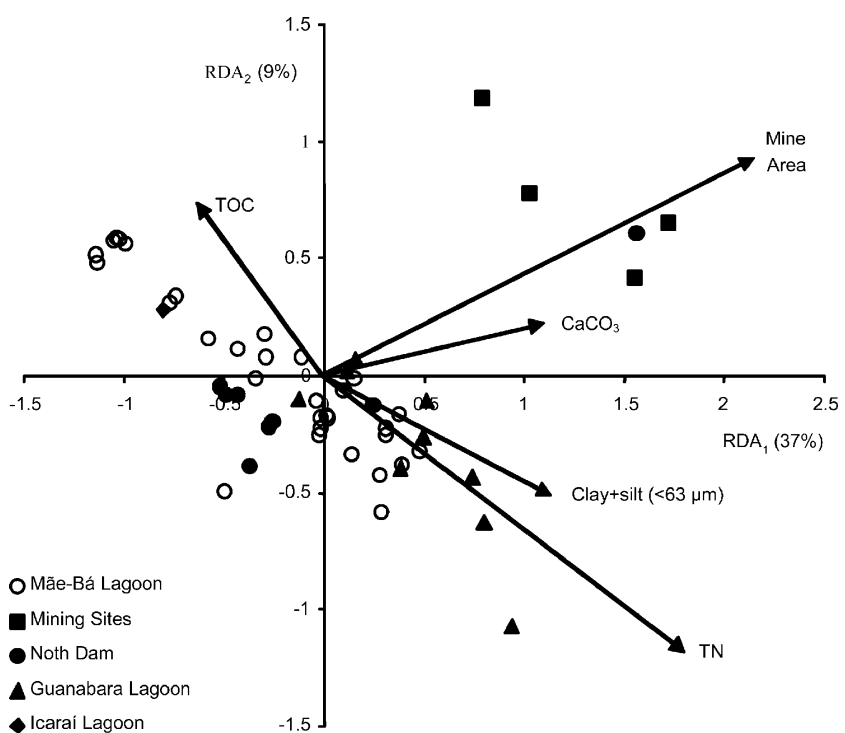

Fig. 2 Scatter space plot of the first two components of redundancy analysis $(R D A)$, including metal, sediment characteristics and locations. Data $(N=53)$ from 14 stations. Eigen vectors of the environmental variables were multiplied by 5

sediments, as described previously (Salomons and Förstner 1984).

The metal enrichment in the sediment profiles at North Dam reflected the anthropogenic influence of the mining activities and ore processing (Mann-Whitney test, $P<0.05$ ). At Mãe-Bá Lagoon, site ML-B reflected its closeness to the North Dam through higher levels of $\mathrm{Fe}, \mathrm{Mn}, \mathrm{Cr}, \mathrm{Ni}$, and $\mathrm{Hg}$ in the surface layers (Mann-Whitney test, $P<0.05$ ). These metal levels were also higher than those observed at the other locations at Mãe-Bá Lagoon (one sample $t$ test, $P<0.05$ ). The sites ML-C, ML-G, and GL showed higher concentrations at the top layers for some metals, but also for clay and carbon content, reflecting the role of these phases in binding these pollutants in the sediments.

Values of TOC generally decreased with depth at the studied sites (see Fig. 3). At Mãe-Bá Lagoon, the (C/N)a ratios (see Fig. 3) indicated a mix of autochthonous and allochthonous organic matter in the sediments, but probably with a greater proportion of autochthonous material due to the eutrophic status of the lagoon.

Correlation analyses of metal and sediment characteristics at Mãe-Bá Lagoon showed, as expected, a high correlation between metals and Clay+Silt $(<63 \mu \mathrm{m})$ and TOC contents. High correlation between $\mathrm{Fe}$ and other metals was also found, indicating a scavenging effect by $\mathrm{Fe}$ compounds (oxides, hydroxides, sulfides).

\subsection{Sediment normalization}

To support the identification of the potential sources of metals to Mãe-Bá Lagoon, a geochemical normalization of metals with Clay+Silt $(<63 \mu \mathrm{m})$ content was performed. It showed two major patterns (Fig. 4):

1. The influence from the iron-ore mining and processing on $\mathrm{Fe}, \mathrm{Mn}, \mathrm{Cu}, \mathrm{Hg}, \mathrm{Cr}$, and $\mathrm{Ni}$ levels is clear: data from the mine area sites were projected above the 95\% upper confidence interval of the regression lines. Fe, Mn, and $\mathrm{Cu}$ seem to be related to the natural metal mineralization in the mining area, since site Sela21 was enriched with these metals. Enrichment of $\mathrm{Hg}$, in contrast, is explained by its use in the amalgamation process of gold exploitation during the 18th and 19th centuries in the Iron Quadrangle (Costa et al. 2003), but may also be naturally found with manganese oxides (Windmoller et al. 2007). Additionally, the grinding process of the iron-ore at the Germano site probably contributes to the enrichment of $\mathrm{Cr}$ and $\mathrm{Ni}$ in the dam sites. The grinding balls contain $\mathrm{Fe}-\mathrm{Cr}$ and $\mathrm{Fe}-\mathrm{Ni}$ alloys, which are released to water as the balls are consumed during this process.

2. The pattern shown by $\mathrm{Zn}, \mathrm{Al}$, and $\mathrm{Pb}$. The mining sites were located below the $95 \%$ confidence intervals, indicating that the mining activities did not constitute an important source of these metals to the study area. However, an enrichment of $\mathrm{Pb}$ was recorded in the core of ND, suggesting a connection with the operations at the Ponta Ubu site. Company's historical monitoring of atmospheric emissions shows that $\mathrm{Pb}$ is one of the metals released by the induration process, which uses fossil fuel. This is in line with some studies reporting the presence of trace metals in fossil fuels and their release into atmosphere associated with the exhaustion gases or fine particles during combustion (Huggins et al. 2004; Reddy et al. 2005).

Although Guanabara Lagoon was selected to act as a Reference Lagoon, metal concentrations in the Clay+Silt $(<63 \mu \mathrm{m})$ fraction were lower than at Mãe-Bá Lagoon only for Fe, Mn, and $\mathrm{Zn}$. The dominance of fine particles and the high organic carbon in the sediments probably provided an efficient trap for metals at Guanabara Lagoon. Furthermore, the presence of higher metal content in upper layers of the sediment core suggests that this lagoon may also have been affected by recent anthropogenic sources of trace metals. Atmospheric deposition, especially from industrial areas, can be an important source of metal contamination in coastal areas in Southeast of Brazil (Lacerda et al. 2002; Lacerda and Ribeiro 2004). As there are no other industrial or urban sources in the vicinity, it may have been possible that the prevailing NE winds have transported metals released by the induration furnaces from the pelletizing plant to Guanabara Lagoon, which was previously assumed to be an undisturbed reference location. 

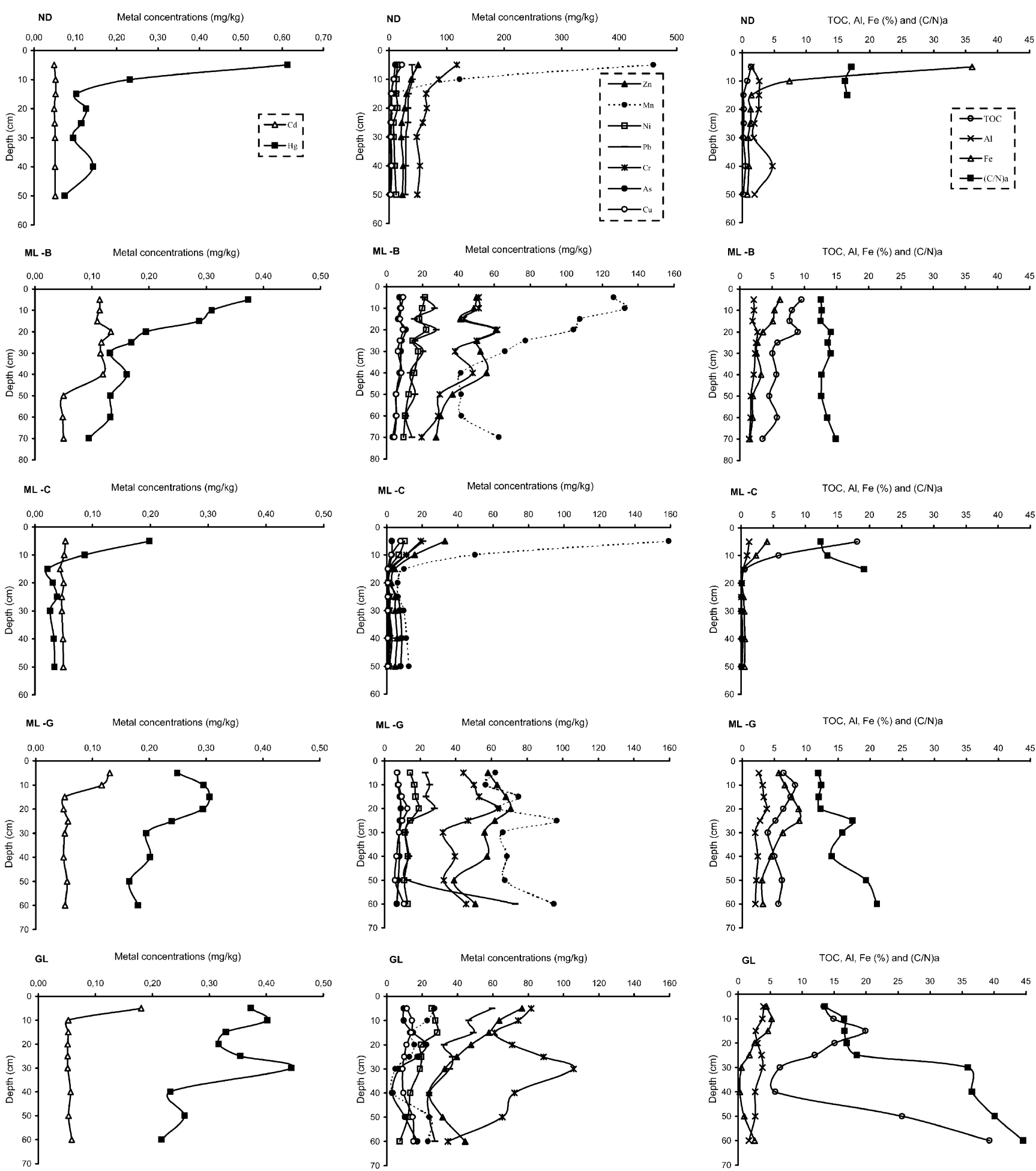

Fig. 3 Metal, TOC, and (C/N)a profiles at North Dam (ND), Mãe-Bá Lagoon (sites ML-B, ML-C, and ML-G) and at Guanabara Lagoon (GL). The legend of the first graph in each column is the same for the graphs below

\subsection{Metals in invertebrates}

To support the assessment of metal bioavailability at the study area, a preliminary assessment of metal uptake by invertebrates was made. Metal levels in invertebrates showed differences between the species collected (Table 4). At Mãe-Bá Lagoon, the gastropod $M$. tuberculata concentrated more $\mathrm{Fe}, \mathrm{Pb}, \mathrm{Ni}$, and $\mathrm{Hg}$ than the other species, while $P$. haustrum concentrated more Mn (MannWitney Test, $P<0.05$ ). These findings confirm that gastro- 

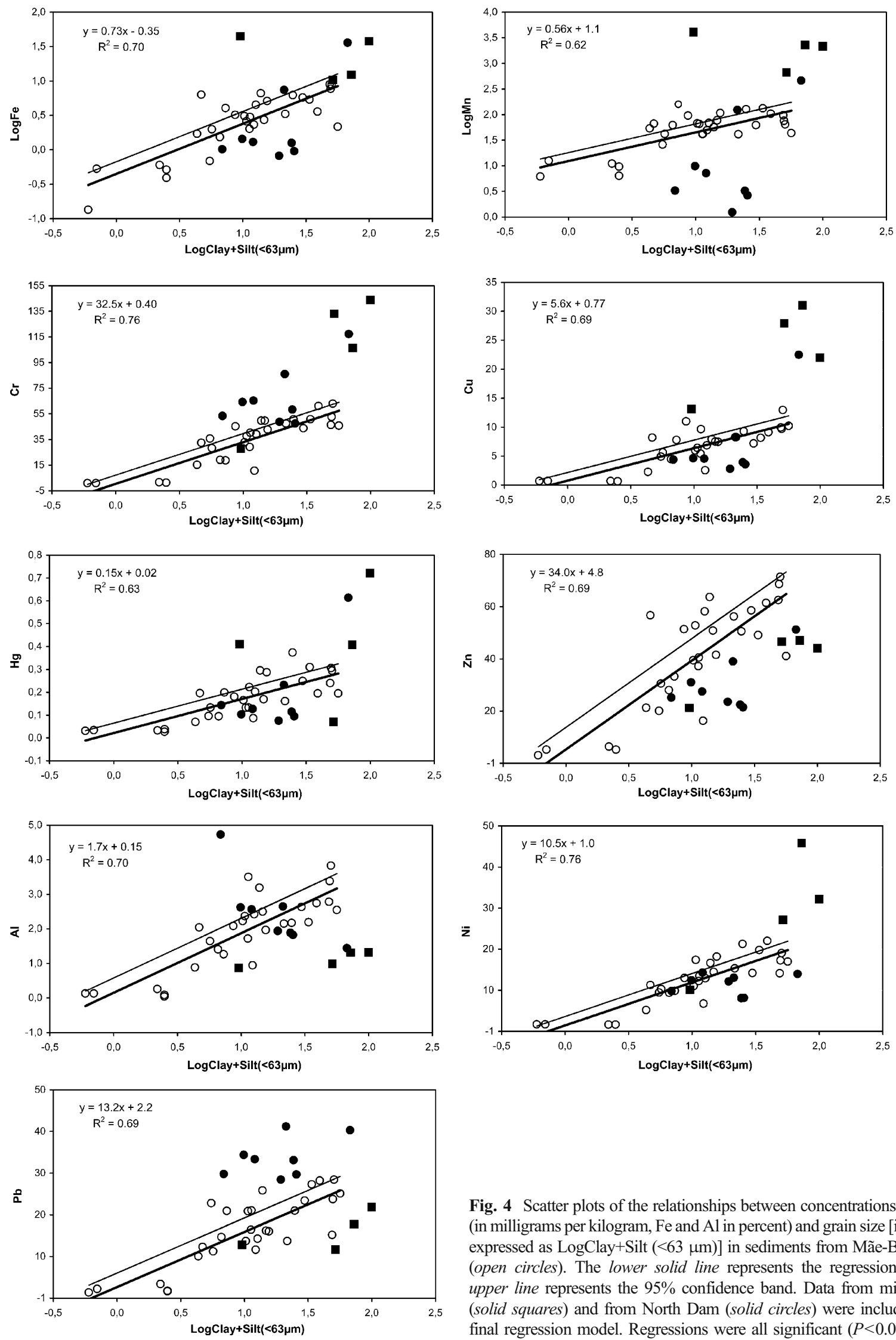

Fig. 4 Scatter plots of the relationships between concentrations of metals (in milligrams per kilogram, $\mathrm{Fe}$ and $\mathrm{Al}$ in percent) and grain size [in percent, expressed as LogClay+Silt $(<63 \mu \mathrm{m})]$ in sediments from Mãe-Bá Lagoon (open circles). The lower solid line represents the regression line; the upper line represents the $95 \%$ confidence band. Data from mining sites (solid squares) and from North Dam (solid circles) were included in the final regression model. Regressions were all significant $(P<0.001)$ 
Table 4 Metal concentrations in invertebrates (in d.w.) from North Dam (ND), Mãe-Bá Lagoon (ML-A to ML-G and combined site ML-ABD) and from the Reference Lagoons (GL and IL)

\begin{tabular}{|c|c|c|c|c|c|c|c|c|c|c|c|c|c|}
\hline Site & Species & $N$ & $\begin{array}{l}\mathrm{Fe} \\
(\mathrm{mg} / \mathrm{kg})\end{array}$ & $\begin{array}{l}\mathrm{Mn} \\
(\mathrm{mg} / \mathrm{kg})\end{array}$ & $\begin{array}{l}\text { Al } \\
(\mathrm{mg} / \mathrm{kg})\end{array}$ & $\begin{array}{l}\mathrm{Zn} \\
(\mathrm{mg} / \mathrm{kg})\end{array}$ & $\begin{array}{l}\mathrm{Cu} \\
(\mathrm{mg} / \mathrm{kg})\end{array}$ & $\begin{array}{l}\mathrm{Cr}^{\mathrm{a}} \\
(\mathrm{mg} / \mathrm{kg})\end{array}$ & $\begin{array}{l}\mathrm{Pb} \\
(\mathrm{mg} / \mathrm{kg})\end{array}$ & $\begin{array}{l}\mathrm{Ni} \\
(\mathrm{mg} / \mathrm{kg})\end{array}$ & $\begin{array}{l}\mathrm{Cd} \\
(\mathrm{mg} / \mathrm{kg})\end{array}$ & $\begin{array}{l}\text { As } \\
(\mathrm{mg} / \mathrm{kg})\end{array}$ & $\begin{array}{l}\mathrm{Hg} \\
(\mathrm{mg} / \mathrm{kg})\end{array}$ \\
\hline \multirow[t]{2}{*}{ ND } & P. haustrum & 7 & 1,390 & 904 & 221 & 177 & 84 & 1.3 & 0.41 & 1.6 & 0.25 & 2.4 & 0.10 \\
\hline & Hemiptera & 16 & 371 & 63 & 161 & 167 & 39 & 0.83 & 0.18 & 0.35 & 0.03 & 0.24 & 0.05 \\
\hline \multirow[t]{2}{*}{ ML-A } & M. tuberculata & 18 & 6,927 & 185 & 6,341 & 121 & 40 & 3.9 & 2.3 & 2.6 & 0.17 & 2.6 & 0.33 \\
\hline & Macrobrachium sp. & 116 & 177 & 30 & 46 & 98 & 48 & 0.32 & 0.04 & 0.59 & 0.01 & 1.4 & 0.05 \\
\hline \multirow[t]{3}{*}{ ML-B } & P. haustrum & 10 & 1,959 & 1,679 & 274 & 69 & 71 & 0.82 & 0.23 & 0.78 & 0.16 & 3.5 & 0.22 \\
\hline & M. tuberculata & 25 & 1,052 & 107 & 101 & 92 & 30 & 1.2 & 0.52 & 2.7 & 0.10 & 2.7 & 0.48 \\
\hline & Macrobrachium sp. & 32 & 244 & 27 & 190 & 97 & 81 & 0.94 & 0.11 & 0.75 & 0.02 & 1.7 & 0.07 \\
\hline \multirow[t]{3}{*}{ ML-C } & P. haustrum & 1 & 814 & 930 & 406 & 144 & 35 & 1.0 & 0.37 & 0.68 & 0.16 & 3.3 & 0.27 \\
\hline & M. tuberculata & 34 & 5,793 & 221 & 2,838 & 142 & 32 & 3.7 & 2.0 & 5.8 & 0.06 & 3.2 & 0.64 \\
\hline & Macrobrachium sp. & 93 & 275 & 24 & 124 & 86 & 67 & 1.0 & 0.09 & 0.80 & 0.02 & 1.4 & 0.06 \\
\hline \multirow[t]{2}{*}{ ML-D } & M. tuberculata & 28 & 2,393 & 65 & 457 & 97 & 32 & 1.1 & 0.62 & 1.3 & 0.07 & 2.2 & 0.50 \\
\hline & Macrobrachium sp. & 185 & 122 & 21 & 117 & 77 & 53 & 0.37 & 0.04 & 0.05 & 0.01 & 1.4 & 0.02 \\
\hline \multirow[t]{3}{*}{ ML-E } & P. haustrum & 2 & 530 & 273 & 34 & 23 & 7 & 3.2 & 0.24 & 0.30 & 0.17 & 0.80 & 0.08 \\
\hline & M. tuberculata & 42 & 3,860 & 107 & 2,545 & 119 & 32 & 4.4 & 1.6 & 1.8 & 0.08 & 2.3 & 0.73 \\
\hline & Macrobrachium sp. & 58 & 146 & 22 & 149 & 89 & 54 & 0.46 & 0.08 & 0.08 & 0.01 & 1.4 & 0.06 \\
\hline ML-F & Macrobrachium sp. & 117 & 164 & 22 & 176 & 85 & 43 & 0.45 & 0.08 & 0.94 & 0.01 & 0.90 & 0.05 \\
\hline \multirow[t]{2}{*}{ ML-G } & M. tuberculata & 28 & 2,749 & 132 & 1,740 & 126 & 39 & 14 & 0.67 & 2.0 & 0.06 & 2.1 & 0.26 \\
\hline & Macrobrachium sp. & 140 & 176 & 40 & 115 & 85 & 51 & 0.50 & 0.04 & 0.08 & 0.01 & 0.92 & 0.03 \\
\hline ML-ABD & Ucides $\mathrm{sp}$ & 4 & 556 & 30 & 443 & 92 & 35 & 3.7 & 0.22 & 2.3 & 0.05 & 0.75 & 0.08 \\
\hline \multirow{3}{*}{ GL } & P. haustrum & 11 & 20,224 & 4,345 & 2,502 & 55 & 168 & 3.6 & 0.81 & 2.2 & 0.42 & 3.5 & 1.1 \\
\hline & M. tuberculata & 93 & 4,044 & 329 & 575 & 154 & 72 & 1.0 & 0.31 & 1.9 & 0.26 & 2.5 & 0.36 \\
\hline & Macrobrachium sp. & 27 & 154 & 19 & 193 & 118 & 33 & 0.43 & 0.06 & 0.07 & 0.01 & 0.37 & 0.06 \\
\hline IL & Macrobrachium sp. & 166 & 435 & 31 & 513 & 105 & 63 & 0.73 & 0.19 & 2.2 & 0.02 & 1.1 & 0.10 \\
\hline $\mathrm{DL}^{\mathrm{b}}$ & - & - & 1.8 & 0.01 & 1.9 & 0.04 & 0.5 & 0.01 & 0.002 & 0.02 & 0.0002 & 0.002 & 0.01 \\
\hline
\end{tabular}

$N$ is the number of individuals used to compose one sample

${ }^{\mathrm{a}}$ The method applied for $\mathrm{Cr}$ in biota has a limited reliability

${ }^{\mathrm{b}}$ Detection limits

pods, which dwell in the sediments and are deposit feeders, tend to accumulate more metals than other species. The crustacean Macrobrachium sp. had the lowest metal contents, except for $\mathrm{Cu}$. This can be explained by the presence of $\mathrm{Cu}$ in the respiratory protein hemocyanin (Rainbow 2002).

Most metals did not show significant differences in concentrations in the gastropod P. haustrum collected at ND

Table 5 AVS, SEM and fraction of organic carbon $\left(f_{O C}\right)$ of the sediments from the mining area (sites Sela 21, SD, SC-A, and SC-B), North Dam (ND), Mãe-Bá Lagoon (sites ML-A to ML-G) and from the Reference Lagoons (sites GL and IL)

\begin{tabular}{|c|c|c|c|c|c|}
\hline Site & AVS $(\mu \mathrm{mol} / \mathrm{g})$ & $\mathrm{SEM}(\mu \mathrm{mol} / \mathrm{g})$ & $f_{O C}$ & SEM-AVS & {$[\mathrm{SEM}-\mathrm{AVS}] / \mathrm{f}_{\mathrm{OC}}$} \\
\hline Sela21 & $<0.10$ & $0.20(0.20)$ & $0.05(0.001)$ & $0.20(0.20)$ & $4.3(4.3)$ \\
\hline SD & $1.34(0.95)$ & $0.47(0.17)$ & $0.04(0.0001)$ & $-0.87(0.78)$ & $-20(18)$ \\
\hline CS-A & $4.5(5.4)$ & $0.28(0.10)$ & $0.02(0.002)$ & $-4.3(5.3)$ & $-237(286)$ \\
\hline CS-B & $2.4(0.5)$ & $0.56(0.01)$ & $0.04(0.005)$ & $-1.9(0.5)$ & $-46.9(6.2)$ \\
\hline ND & $356(8)$ & $0.89(0.17)$ & $0.05(0.01)$ & $-356(8)$ & $-6,754(1,950)$ \\
\hline ML-A & $11.4(1.6)$ & $2.3(1.8)$ & $0.22(0.01)$ & $-9.1(0.1)$ & $-40.6(1.9)$ \\
\hline ML-B & $0.28(0.20)$ & $1.2(1.0)$ & $0.12(0.0003)$ & $0.9(1.2)$ & $7.8(10.4)$ \\
\hline ML-C & $56(14)$ & $0.62(0.17)$ & $0.14(0.05)$ & $-56(13)$ & $-458(278)$ \\
\hline ML-D & $2.1(0.04)$ & $0.85(0.11)$ & $0.21(0.01)$ & $-1.2(0.1)$ & $-5.8(1.1)$ \\
\hline ML-E & $3.5(0.6)$ & $0.63(0.44)$ & $0.13(0.01)$ & $-2.8(0.2)$ & $-22.7(1.3)$ \\
\hline ML-F & $2.7(2.3)$ & $0.34(0.26)$ & $0.11(0.07)$ & $-2.3(2.1)$ & $-19.5(7.1)$ \\
\hline ML-G & $0.48(0.03)$ & $0.47(0.002)$ & $0.14(0.01)$ & $-0.02(0.03)$ & $-0.12(0.23)$ \\
\hline GL & $4.3(2.0)$ & $0.59(0.23)$ & $0.19(0.01)$ & $-3.7(2.3)$ & $-19.4(11.4)$ \\
\hline IL & $0.32(0.23)$ & $0.06(0.01)$ & $0.02(0.003)$ & $-0.25(0.24)$ & $-14.9(12.2)$ \\
\hline
\end{tabular}

Data are from duplicates, expressed as average and (standard deviation) 
compared to those collected at Mãe-Bá Lagoon (one sample $t$ test, $P>0.05$ ). The only exceptions were $\mathrm{Ni}$ and $\mathrm{Cd}$. Although ND showed generally higher metal levels in its sediments, metal bioavailability is probably reduced in this site.

Metal concentrations within the same species ( $P$. haustrum and $M$. tuberculata) were usually higher in organisms collected at Guanabara Lagoon than those collected at MãeBá Lagoon (one sample $t$ test, $P<0.05$ ). This reflects the differences in metal levels in sediments between these two sites and suggests higher bioavailability at Guanabara Lagoon.

\subsection{Metal speciation and effects on bioavailability}

Simulations using CHEAQS at Mãe-Bá Lagoon showed metal speciation similar to the sites influenced by the mining operations: $\mathrm{Fe}$ and $\mathrm{Al}$ were dominated by hydroxides ligands, while $\mathrm{Cu}, \mathrm{Ni}, \mathrm{Pb}, \mathrm{Zn}$, and $\mathrm{Mn}$ were characterized by carbonate complexes. Besides being bound to hydroxyl ligands, $\mathrm{Hg}$ was also predicted as chloride complexes $[\mathrm{HgCl}$ $(\mathrm{OH})$ and $\mathrm{HgCl}_{2}$ ]. The main difference in metal speciation at Mãe-Bá Lagoon compared to the other sites was the presence of higher fractions of metal-organic matter complexes, especially for $\mathrm{Cu}(60 \%)$ and $\mathrm{Ni}(35 \%)$. The competition of other cations for ligands, such as $\mathrm{Ca}^{2+}$ and $\mathrm{Na}^{2+}$, seems to have low importance considering the high availability of ligands in Mãe-Bá Lagoon. In contrast, metal speciation in the Reference Lagoons (GL and IL) was dominated mainly by the free aquo ions species.

Concentrations of AVS in the study area had a wide range, from levels lower than the detection limit $(<0.1 \mu \mathrm{mol} / \mathrm{g})$ at Sela21 to very high concentration $(356 \pm 8 \mu \mathrm{mol} / \mathrm{g})$ at North Dam (Table 5). Levels of AVS at ND may explain low metal bioavailability to invertebrates and had the same magnitude as those observed in other sulfide-rich sediments, such as in the river estuarine system from Guanabara Bay (Machado et al. 2004). At Mãe-Bá Lagoon, AVS levels were generally low $(0.48$ to $56 \mu \mathrm{mol} / \mathrm{g})$. The SEM-AVS concentrations (see Table 5) were smaller than zero throughout the whole study area, except at Sela21 and one site at Mãe-Bá Lagoon (ML-B), suggesting potential availability of trace metals. However, when normalized to organic matter, all results of SEM-AVS/ $\mathrm{f}_{\mathrm{OC}}$ were lower than the toxicity limit proposed by Di Toro et al. (2002).

Results of metals in water and sediments suggest that the tailing dam and the artificial lake constitute potential sources of metals such as $\mathrm{Fe}, \mathrm{Mn}, \mathrm{Cr}, \mathrm{Cu}, \mathrm{Ni}, \mathrm{Pb}$, As, and $\mathrm{Hg}$ to MãeBá Lagoon. However, they also change the water chemistry of the lagoon by elevating the content of dissolved ions such as carbonate, hydroxide, sulfate, $\mathrm{Na}$, and $\mathrm{Ca}$. This effect contributes to low metal bioavailability in the lagoon, which is further reduced by the presence of DOC and chloride. In the lagoon's sediments, oxy-hydroxides of Fe and $\mathrm{Mn}$, together with humic acids (organic matter), seem to be the most important factors regulating the amounts of free or biologically available metals and the metal exchange between the biota and water.

\section{Conclusions}

This study has demonstrated the contrasting effects of iron-ore mining and processing on metal release, speciation, and bioavailability in an impacted tropical coastal lagoon. On one hand, iron-ore mining and processing constitute potential sources of metals to the lagoon, on the other hand they also contribute to reducing metal bioavailability. The low metal bioavailability in the lagoon is mainly because of the high content of ligands, partly released by the mining, such as carbonates, and partly naturally found in the lagoon, such as DOC and chloride. Metal bioavailability in the lagoon is further reduced by the presence of organic matter in its sediments. This is confirmed by the low metal levels recorded in invertebrates. Paradoxically, metal levels in the lagoon, with exception of Fe, $\mathrm{Hg}$ and As, were generally at the same levels as in noncontaminated sites and below the Brazilian standards.

Acknowledgements We thank R. Verweij from the Department of Animal Ecology (Vrije Universiteit Amsterdam) for providing equipment for metal analyses in sediments (AAS and GFA-AAS) and O. J. Epema from RIZA (Institute for Inland Water Management and Waste Water Treatment, The Netherlands) for the analyses of $\mathrm{Hg}$, As, and metals in water and invertebrates. We also thank C.P. Swart from the Institute for Environmental Studies (Vrije Universiteit Amsterdam) for assistance and training in metal analyses, A. Poot from the Department of Environmental Sciences (Wageningen University) for training in AVS measurements, and A.R. Gobo from Centro de Biociências e Biotecnologia (UENF) for support with fieldwork. We acknowledge support for this research from Samarco Mineração S/A and from CAPES (Ministry of Education, Brazil), which provided the scholarship for the first author (process number 2637/04-9).

Open Access This article is distributed under the terms of the Creative Commons Attribution Noncommercial License which permits any noncommercial use, distribution, and reproduction in any medium, provided the original author(s) and source are credited.

\section{References}

APHA (1998) Standard methods for the examination of water and wastewater, 20th edn. APHA, Washington, DC

Brasil (2004) Resolução N 344, de 25 de março de 2004. Conselho Nacional de Meio Ambiente (CONAMA)

Brasil (2005) Resolução N 357, de 17 de março de 2005. Conselho Nacional de Meio Ambiente (CONAMA)

Costa AT, Nalini HA, Lena JC, Friese K, Mages M (2003) Surface water quality and sediment geochemistry in the Gualaxo do Norte basin, eastern Quadrilátero Ferrífero, Minas Gerais, Brazil. Environ Geol 45:226-235

de Mello JWV, Roy WR, Talbott JL, Stucki JW (2006) Mineralogy and arsenic mobility in arsenic-rich Brazilian soils and sediments. J Soils Sediments 6:9-19 
Di Toro DM, Mahony JD, Hansen DJ, Scott KJ, Carlson AR, Ankley GT (1992) Acid volatile sulfide predicts the acute toxicity of cadmium and nickel in sediments. Environ Sci Technol 26:96101

Di Toro DM, Hansen DJ, McGrath J, Berry WJ (2002) Predicting the acute toxicity of metals in sediments using organic carbonnormalized SEM and AVS. Technical Report, HydroQual, Inc., Mahwah

Everitt B, Dunn G (2001) Applied multivariate data analysis, 2nd edn. Arnold, London

Holopainen IJ, Holopainen AL, Hamalainen H, Rahkola-Sorsa M, Tkatcheva V, Viljanen M (2003) Effects of mining industry waste waters on a shallow lake ecosystem in Karelia, north-west Russia. Hydrobiologia 506:111-119

Huggins FE, Huffman GP, Linak WP, Miller CA (2004) Quantifying hazardous species in particulate matter derived from fossil-fuel combustion. Environ Sci Technol 38:1836-1842

Knoppers BA, Lacerda LD, Patchineelam SR (1990) Nutrients, heavy metals and organic micropollutants in an eutrophic Brazilian lagoon. Mar Pollut Bull 21:381-384

Lacerda LD, Salomons W (1997) Mercury from gold and silver mining: a chemical time bomb? Springer, Berlin, p 146

Lacerda LD, Goncalves GO (2001) Mercury distribution and speciation in waters of the coastal lagoons of Rio de Janeiro, SE Brazil. Mar Chem 76:47-58

Lacerda LD, Ribeiro MG (2004) Changes in lead and mercury atmospheric deposition due to industrial emissions in Southeastern Brazil. J Braz Chem Soc 15:931-937

Lacerda LD, Carvalho CEV, Rezende CE, Pfeiffer WC (1993) Mercury in sediments from the Paraiba do Sul River continental shelf, S.E. Brazil. Mar Pollut Bull 26:220-222

Lacerda LD, Paraquetti HM, Rezende CE, Silva LFF, Silva-Filho EV, Marins RV, Ribeiro MG (2002) Mercury concentrations in bulk atmospheric deposition over the coast of Rio de Janeiro, Southeast, Brazil. J Braz Chem Soc 13:165-169

Loring DH, Rantala RTT (1992) Manual for the geochemical analyses of marine sediments and suspended particulate matter. Earth-Sci Rev 32:235-283

Machado W, Carvalho MF, Santelli RE, Maddock JEL (2004) Reactive sulfides relationship with metals in sediments from an eutrophicated estuary in Southeast Brazil. Mar Pollut Bull 49:89-92

Marins RV, Lacerda LD, Paraquetti HM, de Paiva EC, Villas Boas RC (1998) Geochemistry of mercury in sediments of a sub-tropical coastal lagoon, Sepetiba Bay, Southeastern Brazil. B Environ Contam Tox 61:57-64

Matschullat J, Perobelli Borba R, Deschamps E, Figueiredo BR, Gabrio T, Schwenk M (2000) Human and environmental contamination in the Iron Quadrangle, Brazil. Appl Geochem 15:181-190

Mirlean N, Andrus VE, Baisch P, Griep G, Casartelli MR (2003) Arsenic pollution in Patos Lagoon estuarine sediments, Brazil. Mar Pollut Bull 46:1480-1484

Pereira AA, Andrade-Filho MC, Mendonça ASF (2006) Aspectos qualitativos de Águas de Lagoas Costeiras e seus fatores influentes - estudo de caso: Lagoa Mãe-Bá, Espírito Santo. Revista Brasileira de Recursos Hídricos 11:63-77

Pimentel H, Lena Jd, Nalini H (2003) Studies of water quality in the Ouro Preto region, Minas Gerais, Brazil: the release of arsenic to the hydrological system. Environ Geol 43:725-730

Rainbow PS (2002) Trace metal concentrations in aquatic invertebrates: why and so what? Environ Pollut 120:497-507

Ratha DS, Venkataraman G (1995) Environmental impact of iron ore mines in Goa, India. Int J Environ Stud 47:43-53

Reddy MS, Basha S, Joshi HV, Jha B (2005) Evaluation of the emission characteristics of trace metals from coal and fuel oil fired power plants and their fate during combustion. J Hazard Mater 123:242-249

Salomons W, Förstner U (1984) Metals in the hydrocycle. Springer, Berlin

Silva MAL, Rezende CE (2002) Behavior of selected micro and trace elements and organic matter in sediments of a freshwater system in south-east Brazil. Sci Total Environ 292:121-128

Sousa WP, Carvalho CEV, Carvalho CCV, Suzuki MS (2004) Mercury and organic carbon distribution in six lakes from the North of Rio de Janeiro State. Braz Arch Biol Techn 47:139-145

Ter Braak CJF, Smilauer P (2002) CANOCO reference manual and CanoDraw for Windows user's guide: Software for canonical community ordination (version 4.5). Microcomputer Power, Ithaca

van Griethuysen C, Gillissen F, Koelmans AA (2002) Measuring acid volatile sulphide in floodplain lake sediments: effect of reaction time, sample size and aeration. Chemosphere 47:395-400

Verweij W (2005) Equilibria and constants in CHEAQS: selection, criteria, sources and assumptions. Rijksinstituut voor Volksgezondheid en Milieuhygiene, Bilthoven

Windmoller CC, Santos RC, Athayde M, Palmieri HEL (2007) Distribution and speciation of mercury in sediments from gold mining sites in iron quadrangle (minas gerais). Quimica Nova 30:1088-1094

Wong MH (1981) Environmental impacts of iron-ore tailings - the case of Tolo Harbor, Hong-Kong. Environm Manage 5:135-145

Zabowski D, Henry CL, Zheng Z, Zhang X (2001) Mining impacts on trace metal content of water, soil, and stream sediments in the Hei River basin, China. Water Air Soil Pollut 131:261-273 